\title{
Stabilizing effects of seagrass meadows on coastal water benthic food webs
}

\author{
Emilia Jankowska $^{\mathrm{a}, *}$, Loïc N. Michel ${ }^{\mathrm{b}, 1}$, Gilles Lepoint ${ }^{\mathrm{b}}$, Maria Włodarska-Kowalczuk ${ }^{\mathrm{a}}$ \\ a Institute of Oceanology Polish Academy of Sciences, Powstańców Warszawy 55, Sopot 81-712, Poland \\ ${ }^{\mathbf{b}}$ Freshwater and Oceanic Sciences Unit of reSearch (FOCUS), Laboratory of Oceanology, University of Liège, Liège, Belgium
}

\section{A R T I C L E I N F O}

\section{Keywords:}

Zostera

Seasonal variations

Benthic fauna

Ecosystem resilience

Stable isotopes

Mixing models

Isotopic niche.

\begin{abstract}
A B S T R A C T
Seagrass meadows ecosystem engineering effects are correlated to their density (which is in turn linked to seasonal cycles) and often cannot be perceived below a given threshold level of engineer density. The density and biomass of seagrass meadows ( $Z$. marina) together with associated macrophytes undergo substantial seasonal changes, with clear declines in winter. The present study aims to test whether the seasonal changes in the density of recovering seagrass meadows affect the benthic food webs of the southern Baltic Sea (Puck Bay). It includes meiofauna, macrofauna and fish of vegetated and unvegetated habitats in summer and winter seasons. Two levels of organization have been tested - species-specific diet preferences using stable isotopes $\left(\delta^{13} \mathrm{C}, \delta^{15} \mathrm{~N}\right)$ in Bayesian mixing models (MixSIAR) and the community-scale food web characteristics by means of isotopic niches (SIBER). Between-habitat differences were observed for grazers, as a greater food source diversity in species from vegetated habitats was noted in both seasons. Larger between-habitat differences in winter were documented for suspension/detritus feeders. The community-wide approach showed that the differences between the habitats were greater in winter than in summer (as indicated by the lower overlap of the respective isotope niches). Overall, the presence of seagrass meadows increased ecological stability (in terms of the range of food sources utilized by consumers) in the faunal assemblage, while invertebrates from unvegetated areas shifted their diet to cope with winter conditions. Therefore, as a more complex system, not sensitive to seasonal changes, Z. marina meadows create a stable habitat with high resilience potential.
\end{abstract}

\section{Introduction}

Marine seagrass meadows are one of the most productive and diverse systems in the coastal waters (Hemminga and Duarte, 2000). Seagrasses play an important role as habitat-forming species: they add additional structure to sea bed architecture, provide a shelter and substrate for numerous benthic species, and provide a direct food source for grazing invertebrates (Gartner et al., 2013). They can also act as ecosystem engineers because they can modify the water flow regimes and sedimentation rates and hence food supplies for benthic organisms (Hemminga and Duarte, 2000). Ecosystem engineering effects are correlated to engineering organism density and often cannot be perceived below a given threshold of engineer density (Harley and O'Riley, 2011, Włodarska-Kowalczuk et al., 2014). That is often linked to the seasonality of engineering species occurrence or abundance.

It has been demonstrated that in the southern Baltic Sea (Puck Bay) seagrass vegetation persists throughout the year, but both the shoot density and aboveground biomass of the plant as well as the abundance and diversity of associated macrophytes undergo substantial seasonal changes, with clear declines in winter (Jankowska et al., 2014). Strong positive effects of increased vegetation cover were observed on macrofaunal species richness, diversity, and composition (WłodarskaKowalczuk et al., 2014). The effects persisted throughout the year, but their magnitude varied seasonally, in parallel with the seasonal development pattern of macrophyte cover. The largest contrast between the two habitats in terms of macrofauna abundance, biodiversity and biomass were documented in July, when meadows reached their maximum plant density and diversity (Włodarska-Kowalczuk et al., 2014). Therefore, the seasonal fluctuations in eelgrass density seemed to influence its engineering effects, as indicated by the changes in macrobenthic standing stocks and community structure. Moreover, the application of mixing models and biochemical trophic markers (stable isotopes and fatty acids) has provided evidence that in summer, the eelgrass meadows modified how the food web structure functions in this area (Jankowska et al., 2018). Although little direct consumption of seagrass tissues was observed, vegetation impacted the benthic food web indirectly by increasing the number of food sources utilized by primary consumers and by supporting larger standing stocks of prey

\footnotetext{
* Corresponding author.

E-mail address: ejankowska@iopan.gda.pl (E. Jankowska).

${ }^{1}$ Current address: Ifremer, Centre de Bretagne, REM/EEP, Laboratoire Environnement Profond, F ${ }^{-29280}$ Plouzané, France.
} 


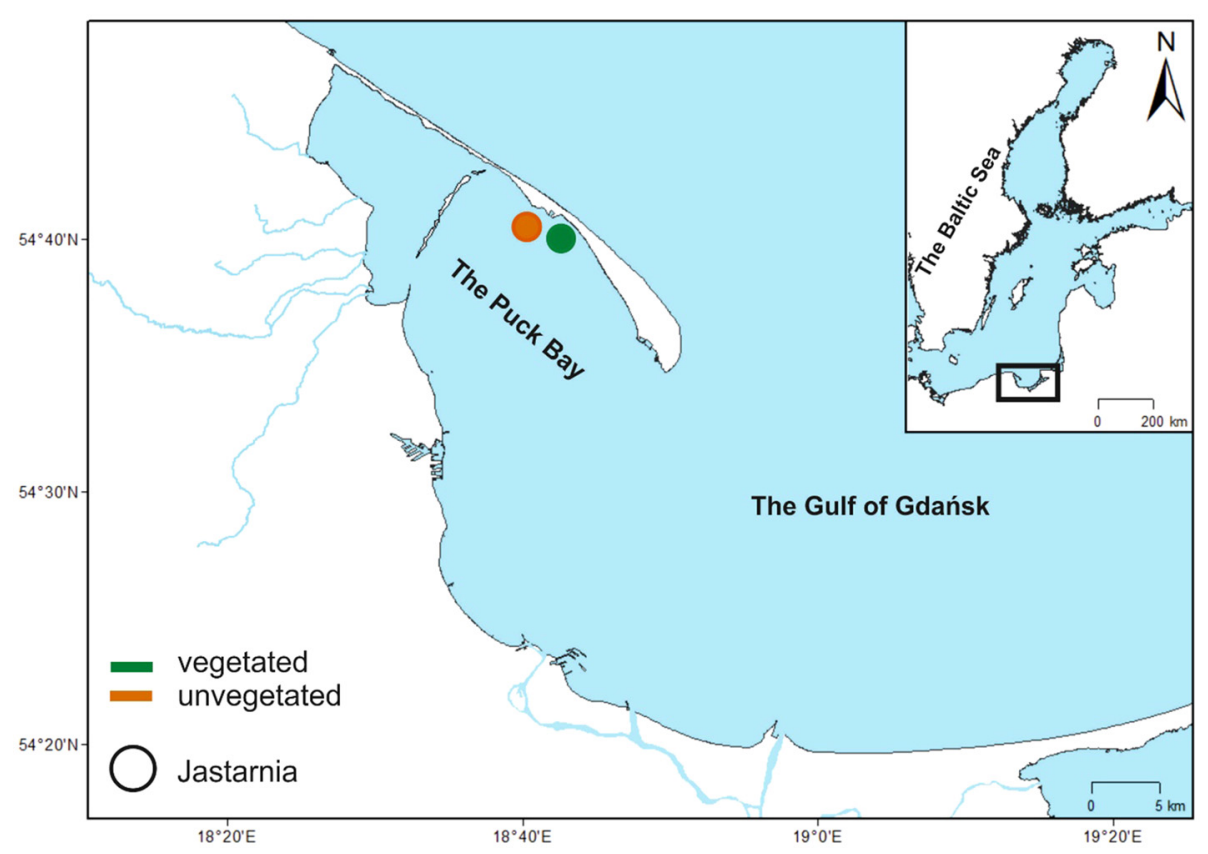

Fig. 1. Study area with indication of sampling points near Jastarnia port in the Puck Bay (Baltic Sea).

organisms and thereby increasing the feeding efficiency at higher trophic levels. It has been concluded that recovering, temperate seagrass meadows, despite their low plant density, can increase the trophic complexity of associated communities and thus play a key role in the energy flow through benthic ecosystems (Jankowska et al., 2018).

A clear signal of food web modification by seagrass vegetation was observed based on materials collected in summer, when the vegetation development was at its maximum (Jankowska et al., 2018). The question whether these effects persist throughout the year, regardless of the seasonality in the plant vegetation development, remains unresolved. It is important to understand the functioning of the system in winter, the season with scarce vegetation and with frequent extreme weather events (storms, ice cover), and with regard to the potential stabilizing role of seagrass cover. Even low-density seagrass canopy can attenuate the effects of hydrodynamic pressures on coastal sediments and thus provide a more stable habitat for benthic biota (Christianen et al., 2013). In addition, winter in the Baltic Sea is characterized by low to absent phytoplanktonic or microphytoplanktonic biomass. Therefore, seagrass biomass could function as alternative food sources, thus stabilizing the local food web.

Stable isotope ratios of carbon $\left(\delta^{13} \mathrm{C}\right)$ and nitrogen $\left(\delta^{15} \mathrm{~N}\right)$ have become widespread and powerful trophic markers, as the stable isotope compositions of consumers reflect those of their food (Deniro and Epstein, 1981). Isotopic mixing models are increasingly used to convert the isotopic data into estimates of food source contributions to an animal's diet (Phillips et al., 2014). Moreover, the stable isotope composition of a population or a species can be used to depict an "isotopic niche" (Jackson et al., 2011) that can, in turn, be used as a proxy of a population or species' realized ecological niche (Bearhop et al., 2004). Those two complementary methods (mixing models and isotopic niche descriptors) have benefited from recent numerical advances based on Bayesian inference. This statistical approach allows taking uncertainty into account, which increases model performance (Moore and Semmens, 2008; Jackson et al., 2011), and the number of publications based on its applications is rapidly growing (Phillips et al., 2014). The size of the isotopic niche has been shown to be related to ecosystem fragmentation (Layman et al., 2007), changes in food availability (Lehmann et al., 2002), and responses of individual consumers to seasonal environmental variability (Martínez del Rio et al., 2009).

Here, we used stable isotope markers to investigate the seasonal changes in food web structure in vegetated and unvegetated coastal areas of the Baltic Sea. Two levels of biotic organization were explored: species-specific diet preferences were depicted using stable isotopes in Bayesian mixing models (MixSIAR), and community-scale food web characteristics were described by isotopic niche characteristics (SIBER). Two aspects of the variability were studied. First, we tested if the differences between the habitats (higher diversity of food sources consumed by grazers and higher contributions of carnivore prey in a diet of omnivores in seagrass system compared to bare bottom) reported by Jankowska et al. (2018) that occurred in summer persisted also in winter. We hypothesized (hypothesis 1 ) that since the macrophyte vegetation and macrobenthic standing stocks decline in winter, so will the contrasts between the habitats. Second, we examined the magnitude of the seasonal variability within each habitat. We hypothesized (hypothesis 2) that the seagrass system, although it decreases in importance in winter, provides higher stability for the benthic food web functioning due to the maintenance of a larger and more diverse pool of food sources, more complex faunal community structure and higher environmental stability (i.e., environmental constraint buffer). Describing the trophic connections from the species to the community scale gives us a comprehensive and broad understanding of the energy flow through the two study systems in two seasons.

\section{Materials and methods}

\subsection{Sampling and laboratory analyses}

The samples were collected from Puck Bay, which is located in the southern Baltic Sea off the Polish coast (Fig. 1). Puck Bay forms a considerable part of the Gulf of Gdańsk, and its shallow waters are home to recently recovered Zostera marina meadows. The trajectory of eelgrass presence in Puck Bay has shown dramatic changes over the last century. Extensive eelgrass meadows were present in Puck Bay in the 1950s when most of the bay was overgrown by meadows (KrukDowigałło, 1991). From the late 1950s to the 1980s, degradation of the meadows was observed when eelgrass area amounted only 16.9 ha (Kruk-Dowigałło, 1991). To date, the areal cover of eelgrass meadows in Puck Bay has increased, although the plant density remains low compared to that of other well-developed, temperate Z. marina meadows (Jankowska et al., 2014). Despite strong environmental 
seasonality (average temperature in summer is $24^{\circ} \mathrm{C}$ and in winter $3{ }^{\circ} \mathrm{C}$ with ice cover persisting for two months; wind strength in summer amounts $3-4 \mathrm{~ms}^{-1}$ while in winter heavy storms $\left(15 \mathrm{~ms}^{-1}\right.$ ) occurs), the meadows persist year-round, with significantly lower eelgrass density, biomass and number of associated macrophytes in winter (Jankowska et al., 2014).

Two sampling stations in Puck Bay were selected - one in an eelgrass meadow and one in the neighbouring unvegetated sediment (2.3 km from each other) close to Jastarnia port, at depths of approximately 1.5-2 m (Fig. 1). Samples were collected by scuba divers in the summer and winter seasons (August 2014 and January 2015). The potential food sources sampled included microphytobenthos (upper $2 \mathrm{~cm}$ sediment layer collected with a syringe and extracted in a laboratory); benthic macrophytes, including eelgrass belowground and aboveground structures, filamentous algae (Pylaiella litoralis) and epiphytes (on the surface of the eelgrass leaves, collected by hand); SSOM (surface sediment organic matter, collected with use of cores); and POM (particular organic matter from the water column, collected by hand). The sampled consumers included meiofauna copepods collected from the seagrass leaves and from the upper $2 \mathrm{~cm}$ of sediments with a $42 \mu \mathrm{m}$ mesh size net, macrofauna and fish (collected with a sediment corer (upper $10 \mathrm{~cm}$ ) and a small dredge). Three replicates for each source and consumer at each station were targeted but not achieved in the case of rare macrofauna taxa (Table S1).

Samples were processed in the laboratory immediately after collection following the procedure described by Jankowska et al. (2018). Microphytobenthos were extracted by placing sediment in plastic containers, covering the sediment with $100 \times 150 \mathrm{~mm}$ Whatman lens cleaning tissue and coverslip and exposing them to an artificial white light source. After $24 \mathrm{~h}$, microphytobenthos were scraped off the cover slides. POM samples were pre-filtered through a $320-\mu \mathrm{m}$ sieve to eliminate zooplankton, then filtered through GF/F Whatman glass fibre filters of $0.7 \mu \mathrm{m}$ porosity. Epiphytes were detached from the seagrass leaves by shaking using a vortex mixer $(10 \mathrm{~min})$ and sonication $(2 \times 60$ s, using a Sonifier Transonic Labour 2000). In the study area the density of microphytobenthos is significantly higher at vegetated $\left(5.8 \mu \mathrm{g} \mathrm{g}^{-1}\right)$ comparing to unvegetated sediments $\left(4.0 \mu \mathrm{gg}^{-1}\right)$ (Jankowska et al., 2016).

Meiofauna copepods were extracted from the sediments after exposure to the artificial white light source. Copepods were then kept in pre-filtered sea water, identified and picked under a stereomicroscope (each replicate consisted of 200 individuals). Only two taxa were sufficiently abundant to complete the procedure: Paraleptastacus spinicauda (family Leptastacidae) and Tachidius discipes (family Tachidiidae). Those two taxa are regarded as one of the most common harpacticoida species of sandy shallows along the Polish coast - average density of Tachidius discipes amounts 496 ind. Per m2, whereas Paraleptostacus spinicauda 2179 ind. Per m2 (Drzycimski, 1985, Kotwicki et al. 2014). Macrofauna and fish were kept for $24 \mathrm{~h}$ in pre-filtered seawater and then identified to the species level. Most of the replicate samples consisted of several individuals due to their small size (Table S1). Then, the samples were freeze-dried and ground for stable isotope analysis.

All samples were analysed for $\delta^{13} \mathrm{C}$ and $\delta^{15} \mathrm{~N}$ [\%o] via continuous flow - elemental analysis - isotope ratio mass spectrometry (CF-EAIRMS) at the University of Liège using a vario MICRO cube elemental analyser (Elementar Analysensysteme GmBH, Hanau, Germany) coupled to an IsoPrime100 mass spectrometer (Isoprime, Cheadle, United Kingdom). Prior to the analyses, to remove inorganic carbon for the measurements, the sediment, filters, gastropods and fish samples were acidified with a direct addition of $1 \mathrm{M} \mathrm{HCl}$ (Hedges and Stern, 1984) and then dried again at $60{ }^{\circ} \mathrm{C}$ for $24 \mathrm{~h}$. Sucrose (IAEA-C6, $\delta^{13} \mathrm{C}=-10.8 \pm 0.5 \%$, mean $\pm \mathrm{SD}$ ) and ammonium sulfate (IAEA$\mathrm{N}_{2}, \delta^{15} \mathrm{~N}=20.3 \pm 0.2 \%$, mean $\pm \mathrm{SD}$ ) were used as certified reference materials (CRM). Both CRMs were calibrated against international isotopic references, i.e., the Vienna Pee Dee Belemnite (VPBD) for carbon and Atmospheric Air for nitrogen. The standard deviations of the multi-batch replicate measurements of lab standards (amphipod crustaceans) and Glycine (Merck, Darmstadt, Germany) interspersed among the samples were $0.1 \%$ for $\delta^{13} \mathrm{C}$ and $0.2 \%$ for $\delta^{15} \mathrm{~N}$.

The collection of macrophytes, macrofauna and fish samples undertaken for this research was approved by collection permits issued to a "ZOSTERA. Restitution of key elements of the inner Puck Bay ecosystem," project (no. POIS.05.01.00-00-205/ 09-00) coordinated by Center of Coordination of Environmental Projects and Regional Directorate of Environmental Protection and Nature Conservation at the Pomeranian Voivodship.

\subsection{Data analysis}

The dataset consisted of data on the stable isotope (SI) composition in four main groups of samples: potential food sources, meiofauna copepods (metazoans that retain on $42 \mu \mathrm{m}$ mesh), macrofauna (invertebrates that retain on $0.5 \mathrm{~mm}$ mesh) and fish (Table S1). Macrofauna species and fish were assigned to four feeding groups based on the published literature: suspension feeders (A. improvisus, M. edulis, M. arenaria), suspension/detritus feeders (C. glaucum, M. balthica), grazers (Gammarus spp., Hydrobia spp., Idotea spp., R. peregra, T. fluviatilis, Jaera spp., S. hookei, B. pilosa) and omnivores (C. carinata, Marenzelleria spp., N. ophidion, Palaemon spp., Pomatoschistus spp., S. typhle, H. diversicolor, C. crangon) (Jaschinski et al., 2008; Baeta et al., 2009; Lebreton et al., 2011; Vafeiadou et al., 2013; Michel et al., 2015).

To test for differences in $\delta^{13} \mathrm{C}$ and $\delta^{15} \mathrm{~N}$ among the sources and the consumers from two habitats in two seasons, univariate PERMANOVA tests based on Euclidean distances (non-transformed data) were applied. Two-way tests were performed to assess potential differences among sources and seasons. Three-way tests were performed to identify contrasts among the consumer groups (meiofauna macrofaunal and fish trophic groups) and between the habitats and seasons.

\subsection{Mixing models}

Bayesian stable isotope mixing models were applied to calculate the relative contributions of potential food sources to the diets of meiofauna and macrofauna consumers from the two habitats (vegetated and unvegetated) in two seasons (summer and winter) To meet the methodological requirements of the model, the potential food sources were grouped according to stable isotope composition similarity, so the final set of sources included plants (Zostera and macrophytes tissues), epiphytes (filamentous algae and seagrass epiphytes), microphytobenthos and POM/SSOM. We also included two animal prey types, according to their size: meiofauna prey (corresponding to mean values of stable isotopes of all meiofauna individuals) and macrofauna prey (mean values of stable isotopes of all macrofauna individuals, except omnivores).

Different potential food sources were used in the model for each consumer group based on general knowledge about their feeding preferences (Table S1): meiofauna copepod diets potentially include microphytobenthos, epiphytes and POM/SSOM (De Troch et al., 2005, Mascart et al., 2013); suspension and suspension/detritus feeders potentially feed on microphytobenthos, epiphytes and POM/SSOM (Baeta et al., 2009); grazers potentially feed on microphytobenthos, epiphytes, POM/SSOM and plants (Jaschinski et al., 2008; Lebreton et al., 2011; Ouisse et al., 2012; Vafeiadou et al., 2013; Michel et al., 2015); and omnivores potentially feed on POM/SSOM, plants, meiofauna prey and macrofauna prey (Mittermayr et al., 2014).

Fractionation factors of $0.4 \pm 1.2 \%$ and $2.3 \pm 1.61 \%$ were applied for $\delta^{13} \mathrm{C}$ and $\delta^{15} \mathrm{~N}$, respectively (after McCutchan et al., 2003). The models were run using MixSIAR (R package, Stock et al., 2018) with two factors (fixed factor habitat and random factor species) separately for summer and winter seasons. Models were run for 100,000 iterations, with no resource contribution data defined a priori (uninformative prior). Diagnostic parameters were used to define whether the model performance was satisfactory: Gelman-Rubin Diagnostics smaller than 
1.05, Geweke diagnostics similar among 3 chains. Model outputs (\% of contribution of each source to consumer diet) were presented using modes, $25 \%$ and $95 \%$ credibility intervals of the posterior solutions distribution function.

\subsection{Isotopic niches}

For each season and habitat, the $\delta^{13} \mathrm{C}$ and $\delta^{15} \mathrm{~N}$ of consumers were used to build community-wide isotopic niches using the SIBER (Stable Isotope Bayesian Ellipses in R) version 2.1.3 package (Jackson et al., 2011). SIBER was used to generate bivariate standard ellipses and convex hulls that represent the core (proxy of the trophic and habitat resources most commonly used by the community; Layman and Allgeier, 2012) and total (proxy of all the trophic and habitat resources used by the community) isotopic niches of consumers, respectively. Isotopic niches were also built for producer assemblages sampled in winter and summer. The total area of the convex hulls (TA) and standard ellipses areas (SEA) were calculated and compared among groups. TA is a proxy for the total isotopic niche. It contains all consumers of the assemblages and therefore reflects all resources consumed by animals. SEA, in contrast, is a proxy for a core isotopic niche and represents only the "most typical" consumers. SEA reflect the resources that are most commonly used by a given animal assemblage.

SEA was estimated using a correction for small sample size (SEA $A_{C}$; Jackson et al., 2011). SEA $A_{C}$ is a robust approach when comparing small (i.e., with $n<30$; Syväranta et al., 2013) and/or unbalanced samples.

\section{Results}

\subsection{Stable isotopes composition of sources and consumers}

The composition of both carbon and nitrogen stable isotopes differed significantly among sources but not between seasons, with significant interactions between two factors (PERMANOVA main tests $p<.05$, Table 1 ). The mean $\delta^{13} \mathrm{C}$ values of sources ranged from $-24.0 \%$ (POM) to $-11.2 \%$ (plants) in summer and from $-22.3 \%$ (SSOM unvegetated) to $-12.7 \%$ (plants, Fig. 2) in winter. The mean $\delta^{15} \mathrm{~N}$ values ranged from $1.4 \%$ (SSOM unvegetated) to $5.8 \%$ (filamentous algae) in summer and from $1.3 \%$ (microphytobenthos) to $6.0 \%$ (filamentous algae both from unvegetated habitat) in winter.

The $\delta^{13} \mathrm{C}$ and $\delta^{15} \mathrm{~N}$ values in consumers differed significantly among consumer groups and seasons but not between habitats, with a significant interaction between habitat and season, consumer group and

\section{Table 1}

Results of univariate PERMANOVA tests for differences in stable isotope compositions in potential food sources among sources and between seasons and in consumers among consumer groups, between habitats and between seasons. psF - pseudoF

\begin{tabular}{|c|c|c|c|c|c|}
\hline \multicolumn{3}{|l|}{ Sources } & \multicolumn{3}{|l|}{ Consumers } \\
\hline \multirow[t]{2}{*}{ Factors } & \multicolumn{2}{|c|}{ Main test, psF } & \multirow[t]{2}{*}{ Factors } & \multicolumn{2}{|c|}{ Main test, psF } \\
\hline & ${ }_{\delta} 13_{\mathrm{C}}$ & ${ }_{\delta} 15_{\mathrm{N}}$ & & ${ }_{\delta} 13_{\mathrm{C}}$ & ${ }_{\delta} 15_{\mathrm{N}}$ \\
\hline Sources & $212.3^{* * * *}$ & $21.8^{* * * *}$ & Habitat & 0.8 & 0.3 \\
\hline Seasons & 0.8 & 0.02 & Consumer group & $24.4^{* * * *}$ & $67.9^{* * * * *}$ \\
\hline \multirow{5}{*}{$\begin{array}{l}\text { Sources } \mathrm{x} \\
\text { seasons }\end{array}$} & $7.4^{* * * *}$ & 1.5 & Season & $15.5^{* * * *}$ & $18.0^{* * * * *}$ \\
\hline & & & $\begin{array}{l}\text { Consumer group } \mathrm{x} \\
\text { habitat }\end{array}$ & 1.5 & 1.5 \\
\hline & & & Habitat $\mathrm{x}$ season & $6.2^{*}$ & $7.6^{* * *}$ \\
\hline & & & $\begin{array}{l}\text { Consumer group } \mathrm{x} \\
\text { season }\end{array}$ & $7.6^{* * * *}$ & $4.0^{* * *}$ \\
\hline & & & $\begin{array}{l}\text { Consumer group } \mathrm{x} \\
\text { habitat } \mathrm{x} \text { season }\end{array}$ & $2.8^{*}$ & $4.9^{* *}$ \\
\hline
\end{tabular}

\footnotetext{
*** $p<.001$

*** $p<.01$

${ }^{*} p<.05$.
}

season and among all three factors (PERMANOVA main tests, $p<.05$ ). The isotopic composition of $P$. spinicauda, one of the meiofauna copepod species, was similar regardless of habitat and season. The mean $\delta^{13} \mathrm{C}$ values were $-20.5 \%$ in summer and $-19.5 \% 0$ in winter. Contrastingly, significant between-seasonal and between-habitat differences in isotopic composition were noted for other meiofauna species, such as $T$. discipes. The $\delta^{13} \mathrm{C}$ values in summer were $-17.7 \%$ (vegetated) and $-13.3 \%$ (unvegetated), and in winter, they were $-19.2 \%$ (vegetated) and $-19.9 \%$ (unvegetated) (Fig. 2). The $\delta^{15} \mathrm{~N}$ values of $T$. discipes were higher by $2 \%$ (seagrass beds) and $6.6 \%$ (bare seabed) in winter than in summer.

For macrofauna consumer groups, the $\delta^{13} \mathrm{C}$ and $\delta^{15} \mathrm{~N}$ value ranges were larger in winter than they were in summer. In summer, the $\delta^{13} \mathrm{C}$ values ranged from $-21.7 \%$ (bivalve $C$. glaucum from the unvegetated) to $-14.2 \%$ (crustacea Idotea spp., from the vegetated habitat), and the $\delta^{15} \mathrm{~N}$ values ranged from $5.2 \%$ (crustacea $C$. carinata in the unvegetated) to $11.3 \%$ ( $S$. typhle in the vegetated). In winter, the $\delta^{13} \mathrm{C}$ values ranged from $-22.3 \%$ (bivalve $M$. edulis sampled at bare seabed) to $-14.4 \%$ (gastropod $R$. peregra form seagrass habitat), and the $\delta^{15} \mathrm{~N}$ values ranged from $5.5 \%$ ( $R$. peregra at seagrass) to $13.1 \%$ (polychaeta $H$. diversicolor at bare seabed, Fig. 2).

Seasonal differences in isotopic composition within macrofauna consumers were noted for a few species. Between-seasonal changes in $\delta^{13} \mathrm{C}$ values were noted for gastropods (grazers). A seasonal shift towards higher $\delta^{13} \mathrm{C}$ values in winter was noted for all gastropods, regardless of the habitat e.g., for T. fluviatilis from vegetated habitat ( $-18.8 \%$ in summer versus $-15.5 \%$ in winter) and Hydrobia spp. from unveg habitat ( $-21.7 \%$ in summer versus $-16.5 \%$ in winter). An opposite seasonal trend was noted for other grazers, such as Idotea spp. from the vegetated habitat $(-17.9 \%$ in winter versus $-14.2 \%$ in summer). Between-seasonal changes in $\delta^{15} \mathrm{~N}$ values were noted for omnivores from unvegetated habitat. Both $H$. diversicolor and Marenzelleria spp. had higher $\delta^{15} \mathrm{~N}$ values in winter (by 7.3\%o and $2.5 \%$, respectively).

\subsection{Source contribution to species diet}

The MixSIAR mixing models showed that the diet of $T$. discipes in summer season differed between the habitats. Individuals collected from the vegetated bottom had a higher proportion of epiphytes (mode: $70 \%$ of diet; Bayesian 95\% credibility interval $\left(\mathrm{CI}_{95}\right): 27-81 \%$ ), whereas individuals collected from the unvegetated habitat had a higher microphytobenthos proportion (mode: $63 \%, \mathrm{CI}_{95}: 36-88 \%$ ) in the diet. The mixing models in winter showed that $T$. discipes diet was mostly composed of POM/SSOM regardless of the habitat (mode of solutions for seagrass bed $-92 \%$, for bare seabed $-64 \%$, Fig. 3, Table S3).

In summer, suspension and suspension/detritus feeders had different food sources depending on species and habitats. Epiphytes were the sole food source for the balanoid A. improvisus $\left(96 \%, \mathrm{CI}_{95}\right.$ : 90-100\%) and were a considerable proportion of the food source for $C$. glaucum and M. edulis (proportions 59\%, $\mathrm{CI}_{95}: 35-72 \%$ and $56 \%, \mathrm{CI}_{95}$ : $43-75 \%$ accordingly) from the vegetated habitat. POM/SSOM was the sole food source for $C$. glaucum collected from the unvegetated habitat (92\%, $\mathrm{CI}_{95}$ : 84-100\%), whereas $M$. arenaria had a considerable proportion of epiphytes $\left(40 \%, \mathrm{CI}_{95}: 38-52 \%\right)$ and microphytobenthos/ bacteria (38\%, $\mathrm{CI}_{95}: 27-50 \%$, Fig. 3$)$ in the unvegetated habitat. Within the suspension and suspension/detritus feeders collected in winter, the main food source differed between habitats. For individuals collected from the vegetated habitat, epiphytes were the main food source for $A$. improvisus (54\%, $\mathrm{CI}_{95}: 0-99 \%$ ) and contributed considerably to $M$. arenaria and $M$. baltica (contributions $34 \%, \mathrm{CI}_{95}: 0-47 \%$ and $31 \%, \mathrm{CI}_{95}$ : $0-43 \%$ accordingly). Representatives of all three species collected from the bare seabed had POM/SSOM as a main food source (from 90 to $98 \%$ Fig. 3). Much larger contribution of epiphytes in the diet of $C$. glaucum collected in the vegetated habitat was noted, when the individuals from 


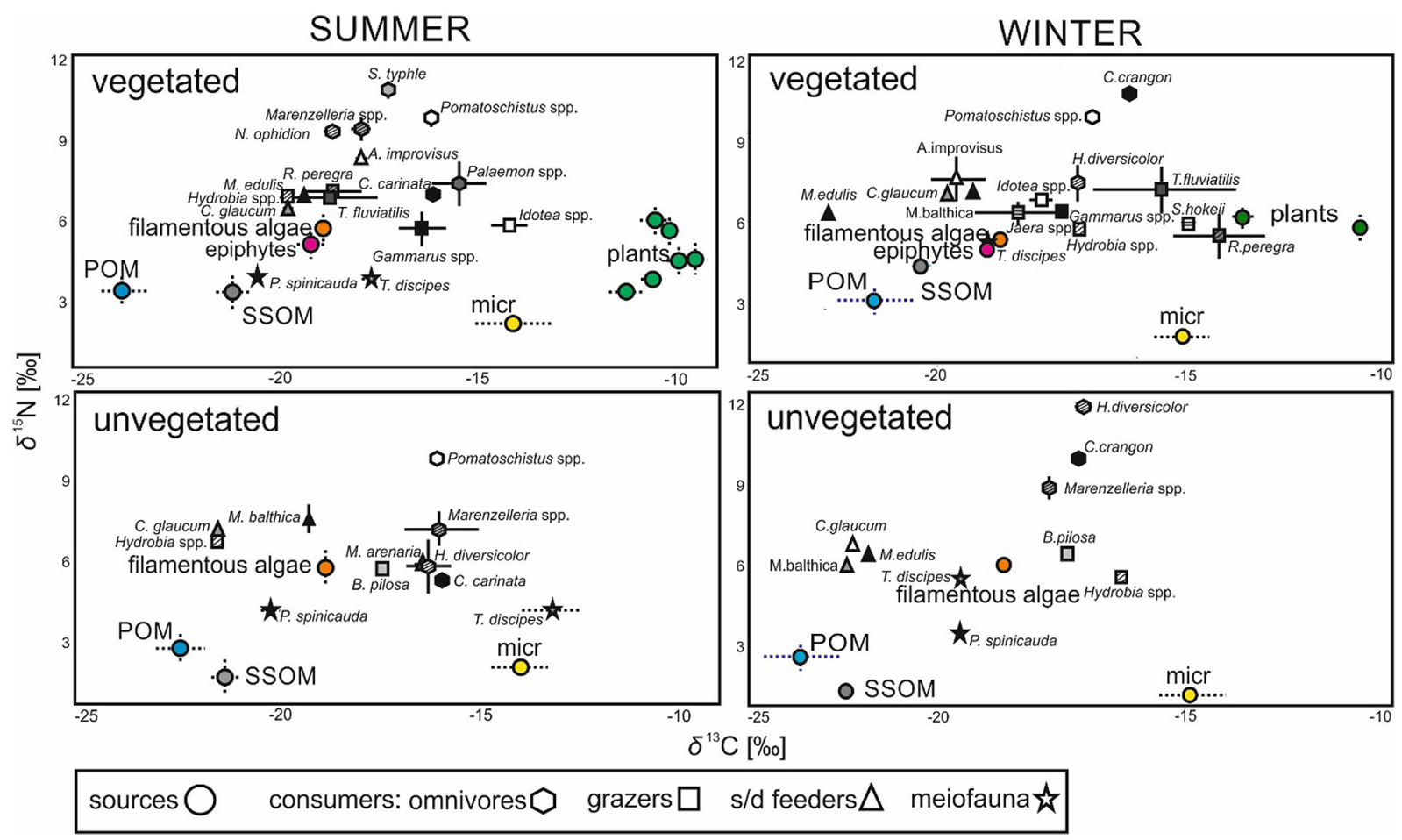

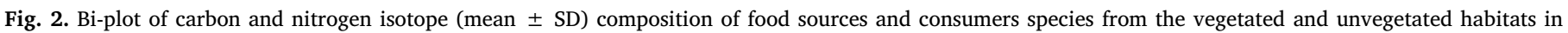
summer and winter seasons in Puck Bay (Baltic Sea) (all values presented in Table S2).

the two habitats were compared in summer. While in winter the same species had similar food sources at both habitats (Table S3).

In summer, four grazer species collected from the vegetated habitat fed mostly on epiphytes: Gammarus spp., Hydrobia spp., R. peregra and T. fluviatilis (mode from 58 to 80\%). POM/SSOM was an important food source for Hydrobia spp. (30\%, $\left.\mathrm{CI}_{95}: 10-52 \%\right)$, while microphytobenthos/bacteria were important for Idotea spp. (39\%, $\mathrm{CI}_{95}$ : $13-61 \%$ ) in the seagrass beds. POM/SSOM was the main food source for B. pilosa (36\%, $\left.\mathrm{CI}_{95}: 0-69 \%\right)$ and the sole food source for Hydrobia spp. $\left(78 \%, \mathrm{CI}_{95}: 40-100 \%\right)$ in the unvegetated habitat. In winter, POM/ SSOM was the main food source in the diet of four grazer species collected from the vegetated habitat: Gammarus spp., Idotea spp., Jaera spp. (modes from 59 to $80 \%$, Table S2). Microphytobenthos/bacteria was a main food source for two grazer species, $R$. peregra $\left(86 \%, \mathrm{CI}_{95}\right.$ : 68-99\%) and $S$. hookei (73\%, $\left.\mathrm{CI}_{95}: 54-94 \%\right)$, in seagrass beds. Moreover, a considerable contribution of plants was noted for T. fluviatilis in the vegetated habitat $\left(55 \%, \mathrm{CI}_{95}\right.$ : $\left.33-92 \%\right)$. POM/SSOM was the main food source for B. pilosa from the unvegetated habitat (59\%, $\mathrm{CI}_{95}$ : 35-81\%). Microphytobenthos/bacteria also contributed greatly to Hydrobia spp. in the unvegetated habitat (43\%, $\left.\mathrm{CI}_{95}: 17-65 \%\right)$ (Fig. 3). The contribution of epiphytes and plants was negligible for all grazers taxa collected from the unvegetated habitat in both seasons. There was only one the same taxa presented in the vegetated and unvegetated habitat and the contribution of food sources in its diet differed between habitats. Hydrobia spp. from the vegetated habitat had higher contribution of epiphytes whereas from the unvegetated had higher contribution of POM/SOM in summer. Whereas, in winter microphytobenthos was main food sources for bivalves in both habitats while POM/SOM only for the one from unvegetated (Table S3).

In summer, four omnivores species collected from the vegetated habitat fed mostly on meiofauna prey: C. carinata, Marenzelleria spp., Palaemon spp. and N. ophidion (modes from 46 to 93\%). For two other species from the vegetated habitat, macrofauna prey was the main food source - S. typhle (93\%, $\left.\mathrm{CI}_{95}: 56-100 \%\right)$ and Pomatoschistus spp. (74\%, $\left.\mathrm{CI}_{95}: 50-100 \%\right)$. In contrast, in the unvegetated habitat, only one species fed on macrofauna prey: Pomatoschistus spp. (83\%, $\left.\mathrm{CI}_{95}: 36-100 \%\right)$.
In the same habitat, SSOM formed the highest proportion of the diets of C. carinata and $H$. diversicolor (modes 33 and 37\%) (Fig. 3, Table S2). In winter, meiofauna and plants contributed considerably to the diet of $C$. crangon in the vegetated habitat $\left(34 \%, \mathrm{CI}_{95}: 0-56,31 \%, \mathrm{CI}_{95}: 8-42 \%\right.$ accordingly). Macrofauna was the main food source for Pomatoschistus spp. (56\%, $\left.\mathrm{CI}_{95}: 24-99 \%\right)$ collected from the vegetated seabed. For specimens collected from the unvegetated habitat, meiofauna prey was an important food source for Marenzelleria spp. (69\%, $\mathrm{CI}_{95}$ : $\left.31-79 \%\right)$, whereas macrofauna prey was important for two other species: $C$. crangon and $H$. diversicolor (modes 45 and 51\%) (Fig. 3). There were three the same species presented in the vegetated and unvegetated habitat in summer and their diet differed between habitats for the two of them. C. carinata and Marenzelleria spp. from seagrass meadows had higher contribution of meiofauna prey in its diet whereas from the bare seabed, higher contribution of POM/SOM. In winter two the same species occurred in both habitats. In the vegetated habitat, the main food source of $C$. crangon was meiofauna prey, while in the unvegetated habitat macrofauna prey. Continuing, H.diversicolor from seagrass consumed mostly POM/SOM, while from the bare seabed, macrofauna prey (Table S3).

\subsection{Isotopic niche modelling}

Isotopic niches of producers occupied a very similar position in the isospace in both summer and winter (Fig. 4). They were strongly overlapping (over $75 \%$ of the cumulated areas), although the summer niche (SEAC: $30.6 \%_{0}^{2}$, TA: $58.2 \%^{2}$ ) seemed slightly larger than the winter one (SEA $: 23.4 \% 0^{2}$, TA: $34.4 \%{ }^{2}$ ).

The differences in the areas of the standard ellipses $\left(\mathrm{SEA}_{\mathrm{C}}\right)$ of communities between the two habitats were greater in winter $\left(10.4 \%{ }^{2}\right.$ - vegetated versus $16.6 \% 0^{2}$ - unvegetated) than in summer $\left(9.5 \% 0^{2}-\right.$ seagrass beds versus $12.2 \%{ }^{2}$ - bare seabed). On the other hand, convex hull areas (TA) of the communities at both habitats were very similar in winter $\left(21.8 \%{ }^{2}\right.$ and $23.0 \% 0^{2}$, respectively) and differed more in summer $\left(18.5 \% 0^{2}\right.$ vegetated, $14.4 \% 0^{2}$ unvegetated). The $\mathrm{SEA}_{\mathrm{c}} / \mathrm{TA}$ ratio was notably higher in unvegetated $(0.85)$ than in vegetated $(0.51)$ areas 


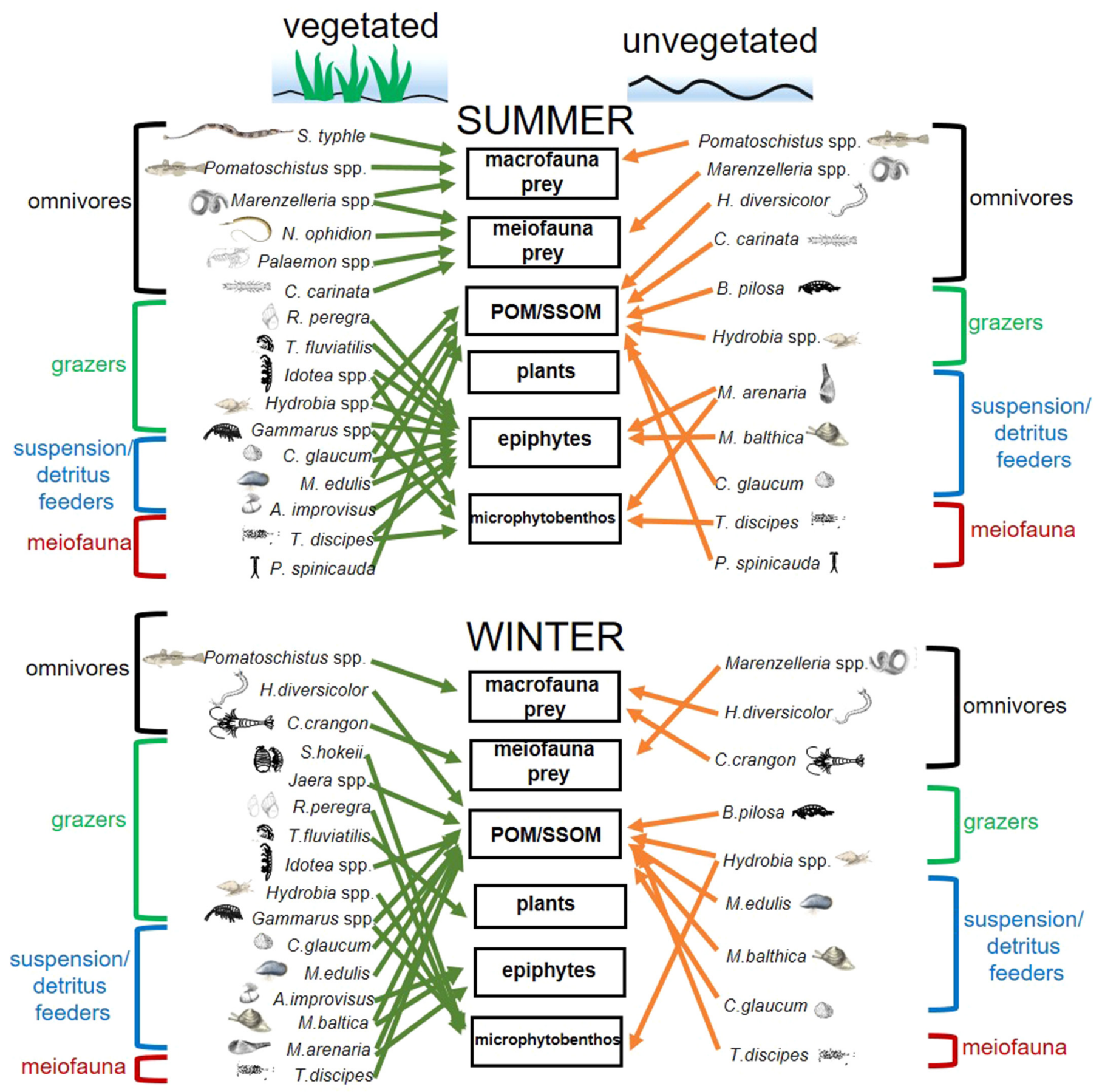

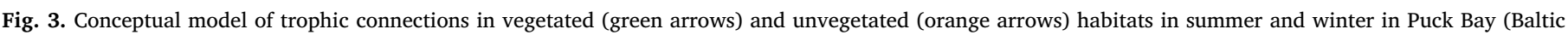

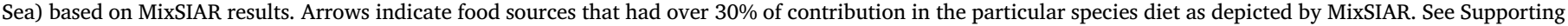

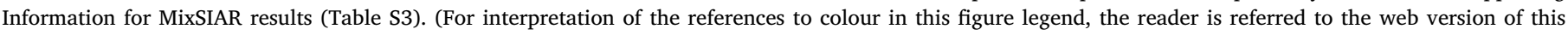
article.)

in both summer and winter ( 0.72 vs. 0.48 ).

Niche positions of vegetated and unvegetated communities were more similar in summer than in winter (Fig. 4), as the relative overlap between the two standard ellipses for the two habitats was greater in summer (approximately 40\% of the cumulative areas of both ellipses) than in winter ( $16 \%$ of the cumulative areas). The largest niche overlap (81\%) was observed for the seagrass habitat in winter and the bare seabed habitat in summer.

\section{Discussion/Conclusions}

\subsection{Seasonal and between-habitat contrasts in consumer diets}

The seasonal changes in meiofauna copepods ( $T$. discipes) sources uptake shows a less diverse diet in winter, based on one major food source (POM/SSOM) in both habitats. Whereas in summer, a considerable contributions from other sources were demonstrated by MixSIAR models (epiphytes in vegetated and microphytobenthos in unvegetated habitat). Seasonal shifts in meiofauna copepod diets have also been detected in $Z$. noltii from the French Atlantic and western 


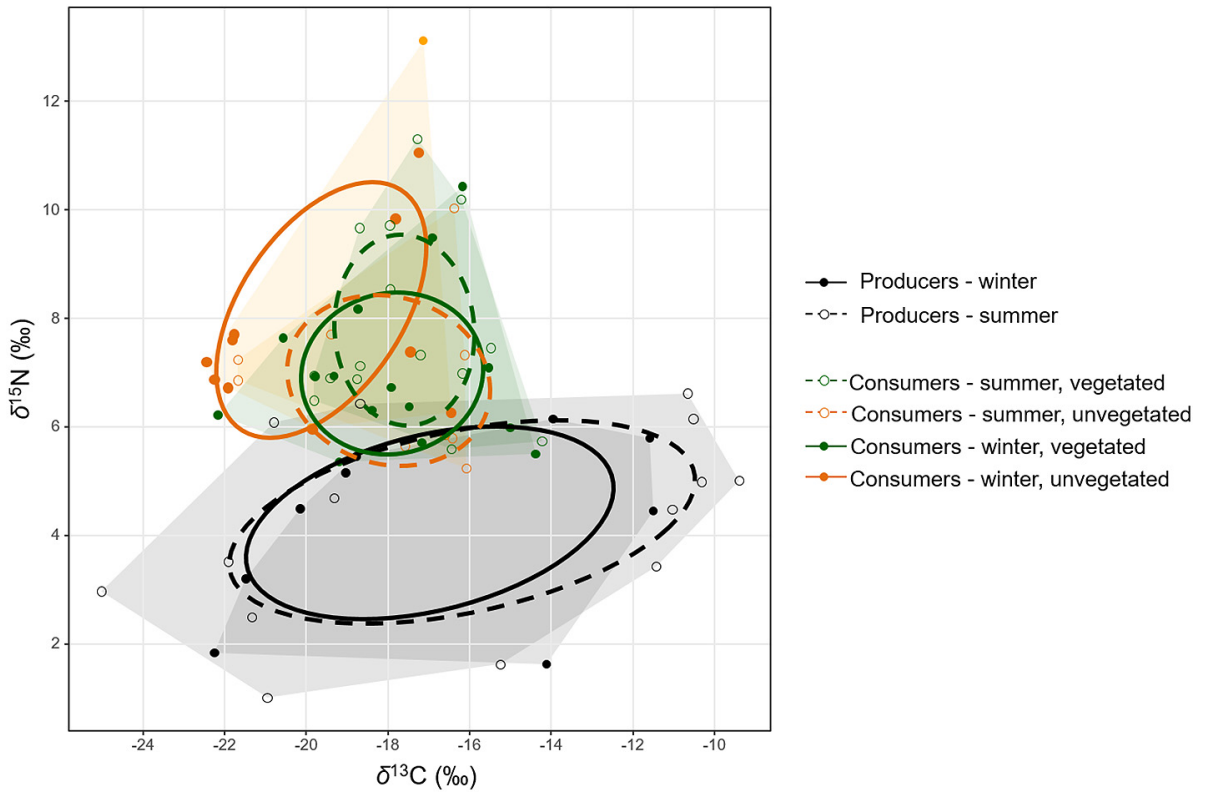

Fig. 4. Isotopic niches of producers and consumers assemblages in Puck Bay (Baltic Sea). Points are mean values for each species or item, solid or dashed lines are standard ellipses (SEA), and shaded areas are convex hulls associated with each group (TA). Black: producers, green: consumers from vegetated habitats; orange: consumers from unvegetated habitats. Open symbols and dashed lines: summer samples, full symbols and solid lines: winter samples. (For interpretation of the references to colour in this figure legend, the reader is referred to the web version of this article.)
Italian coast (Lebreton et al., 2012; Vizzini et al., 2002), although these studies showed different patterns. On the Atlantic coast, the POM contribution in the diet of copepods was greater during spring and summer than in other seasons (Lebreton et al., 2012), while in the Mediterranean Sea, POM was a prevalent food source in winter, and benthic organic matter dominated during other seasons (Vizzini et al., 2002). Benthic copepods are opportunistic feeders that can adjust their diet to the availability of food sources (Lebreton et al., 2012). The dominance of dietary POM/SSOM in both habitats in winter could be a consequence of the lower availability of other, preferable sources in this season. In summer, $T$. discipes from the vegetated habitat most likely lived among densely growing seagrass leaves (covered by filamentous algae) and fed preferentially on epiphytes. In winter, seagrass foliar surface and other macrophytes (including filamentous algae) decreased (Jankowska et al., 2014), so the availability of the preferred food source in summer (epiphytes) decreased dramatically.

The seasonal trends in sources uptake varied among macrofauna species and their groups. Regarding suspension and suspension/detritus feeders, in summer all species fed on a mixture of different food sources in both habitats (epiphytes, POM/SSOM, microphytobenthos). In winter, species from the vegetated habitat still utilized multiple food sources (epiphytes, microphytobenthos, POM, SSOM), while species inhabiting unvegetated bottom fed only on POM/SSOM. The diversity of food sources in the diet of suspension and suspension/detritus feeders in unvegetated habitat in summer may have resulted from the organic matter supply from neighbouring seagrass beds. Carbon inputs associated with seagrass beds were found to extend well beyond the vegetation boundaries and contributed to the diet of macrobenthos in adjacent sediments in coastal Portugal waters (Vafeiadou et al., 2013). Previous studies on $Z$. noltii meadows (French Atlantic coast) noted a lack of seasonal differences in the suspension feeders' diet, which was year-round and based on microphytobenthos resuspended by the waves (Lebreton et al., 2011). In Puck Bay, epiphytes (together with filamentous algae) produce high biomass in summer (Jankowska et al., 2014) but decrease in winter. A considerable contribution of epiphytes and filamentous algae plus a small contribution of plant tissue in the sediment organic matter pool of the bare seabed has been previously detected in Puck Bay in summer (Jankowska et al., 2016). As reflected in the diet of suspension/detritus feeders from the unvegetated habitat, the export of epiphyte-derived organic matter to sandy bottoms is therefore very likely to occur in summer and to cease in winter.

In both summer and winter, some grazers inhabiting vegetated seabeds exhibited higher trophic diversity (i.e., fed on a greater number of distinct food items) than did individuals from unvegetated seabeds. As indicated by the summer food web study in Puck Bay (Jankowska et al., 2018), grazers from vegetated habitat were characterized by selective feeding and so they are in winter (despite of seasonal drop in meadows structure) Epiphytes that greatly contributed to the diet of grazers from the vegetated habitat in summer were barely consumed in winter, but in the absence of epiphytes, some grazers switched to feeding on microphytobenthos (R. peregra, Idotea spp., Gammarus spp., Hydrobia spp.) or even plant tissue (T. fluviatilis). In the unvegetated habitat, the grazers' diet was based mostly on POM/SSOM in summer and POM/SSOM and microphytobenthos in winter. As indicated by a study in the Ligurian Sea, herbivores from meadows fed on epiphytes and seagrass leaves throughout the year (Peirano et al., 2001), but this system did not undergo such strong seasonal changes in vegetation cover as Puck Bay did.

Finally, clear seasonal differences in the diet of omnivores from two habitats were noted. The consumption of animal-derived matter in vegetated habitat was higher in summer, while in winter, carnivory appeared to be common in unvegetated habitats. In summer, carnivores from the vegetated habitat were confronted with greater prey availability than in winter, as both the density and biomass of macrofauna increased in summer (Włodarska-Kowalczuk et al., 2014). It has been noted that the movements of predators in the Baltic Sea follow seasonal changes in prey availability (Nordström et al., 2009). Moreover, the two predatory pipefish species $N$. ophidion and $S$. typhe and the omnivore shrimp species Palaemon spp. noted within the seabed in summer were not present in winter, probably due to seasonal migration to deeper parts of the bay (Jephson et al., 2008; Rutkowski, 1982). Instead, $C$. crangon was present in both habitats. The diet of $C$. crangon in the Baltic Sea consists largely of $B$. pilosa grazer species, which tend to dominate exposed sandy seabeds and have been described as a preferred food item for C. crangon (Pihl and Rosenberg, 1984; Nordström et al., 2009). Indeed, in our study, B. pilosa was only present in the unvegetated bottom, and it was only in this habitat that the diet of $C$. crangon was dominated by macrofaunal prey in winter. In general the between habitat and season differences in predation among omnivorous fauna detected within this study implies a great complexity of this specific feeding group. The combined effects of the habitat and season on the feeding preferences in omnivorous species are to be tested in future research.

Overall, the results of mixing models shows great importance of 
composite food sources (POM/SSOM), epiphytes and microphytobenthos for the whole communities as indicated by high number of connections from species to food sources (Fig. 3). It is highly probable that many species feeding on those composite food sources are actually performing selectivity that might be important for their coexistence and the stability of assemblages. More research to improve diet description of those species by using advanced techniques and more appropriate markers (e.g. stable isotopes analysis in amino acids or PLFA) should be performed in the future (Budge et al., 2008). This could help to better understand fine resource partitioning between species and trophic guilds, as well as to pinpoint key-metabolisms and mechanisms of production and consumption that support many consumer taxa (e.g. importance of bacteria vs. prokaryotes, certain macroalgae more than others) (Wu et al., 2016). It is important from both ecological and biological conservation point of view, as all of the subunits composing POM/SOM, epiphytes/algae or microphytobenthos are likely to react differently to ecosystem changes and anthropogenic activities.

\subsection{Seasonal and between-habitat variability of community trophic niches}

The community-wide approach of comparing food webs from two habitats in two seasons showed that the contrasts between the habitats were stronger in winter than in summer (as indicated by the smaller overlap of the respective isotope niches). There are many sources of variation that contribute to a consumer's isotopic composition, including the geometry of the sources' mixing space, the foraging behaviours of the consumers, and temporal changes in the environment that might alter the consumer's ability to find, acquire, and consume its source (Yeakel et al., 2016). In the present study, the isotopic variability of food sources seemed comparable in both seasons, as suggested by the similar position and size of producers' standard ellipses in both seasons (Fig. 4). Therefore, inter-seasonal differences in fauna diet can be linked to actual ecological shifts rather than isotopic baseline changes. The seasonal shift in community niches could be a result of a phenomenon described above, i.e., support from the neighbouring bare sandy bottom habitat, with organic matter produced within seagrass meadows in summer and a lack of that support in winter (Thormar et al., 2016). Seagrass meadows deposit organic matter to the adjacent bare bottom by materials detached from the meadows (Miyajima et al., 1998) and reducing velocity of the water flow (Fonseca and Koehl, 2006; Pujol and Nepf, 2012). In the present study in summer, both communities fed on a variety of food sources that were supported by the well-developed macrophyte vegetation in the meadows, so the community niches largely overlapped, with only some differences. Further, the seagrass bed community niche was extended vertically towards higher $\delta^{15} \mathrm{~N}$ values due to a higher contribution of prey in omnivore diet, while the bare sand community niche was extended towards more negative $\delta^{13} \mathrm{C}$ values due to the higher contribution of POM/SSOM in the diets of several consumers. In winter, the consumers in the vegetated community still fed on a variety of sources and the overall community niche did not change significantly. In contrast, consumers from bare sand, seemed to restructure their diet strongly towards POM/SSOM and animal prey, resulting in a community isotope niche that clearly shifted towards lower $\delta^{13} \mathrm{C}$ and higher $\delta^{15} \mathrm{~N}$ values.

The ratio between the standard ellipses area (SEA) and convex hulls (TA) areas of consumer assemblages in Puck Bay (Fig. 4) was higher for unvegetated habitats (approximately $80 \%$ in both seasons) than for vegetated communities (approximately 50\%). It implies that animals from the unvegetated habitat commonly exploit a large part of the range of the resources that they can find in their environment. This could be caused by lower food availability and increased competition. It has been previously noted that shift in feeding behaviour of the same species depends on the availability of resources and the time spent handling the food under high predation risk (Rossi et al., 2004; Sommer et al., 2005). Due to lack of vegetation, invertebrates inhabiting bare seabed are indeed under higher predator pressure. On the other hand, in vegetated habitats, the food availability is greater, predation pressure lower and the animals are more likely to feed on preferred food items. That could explain why a smaller proportion (approximately 50\%) of the total available food items seem to be commonly exploited by animals from vegetated habitats. This is particularly marked in summer, where the TA of assemblage is higher (more total isotopic diversity) but the SEA is slightly smaller (less core isotopic diversity) in vegetated than in unvegetated habitats.

\subsection{Stabilizing effects of seagrass meadows on food web structure}

The species-specific and community isotope niche approach application revealed the patterns of seasonal and between-habitat variability in coastal benthic food webs in Puck Bay. Overall, the comparison of community isotopic niches indicated that seagrass cover for the benthic food web is more critical in winter, which is a season with lower resource availability. The presence of seagrass is important not as a potential food source itself but because the presence of seagrass meadows increases ecological stability (in terms of the range of food sources utilized by consumers) in the faunal assemblage associated with underwater vegetation, while invertebrates from unvegetated areas had to shift their diet to adapt to winter conditions. In contrast to our expectations, the differences in trophic diversity between the habitats were greater in winter, even if abundance and diversity of the vegetation decreased in that season. The contrast between the habitats in winter was produced by the strong dietary shift of bare sands fauna. However, the stronger similarity between the two studied habitats in summer may resulted from the meadows influence on sandy sediments via the export of phytodetritus. It would be useful to assess the magnitude and spatial range of this export and to compare the seasonal variability of faunal communities along the gradient of the meadow influence in future studies.

It was previously emphasized that the detrital production of seagrass meadows exerts an important stabilizing effect on the whole ecosystem by providing a persistent food supply (Thormar et al., 2016). Moreover, a study comparing food web structure of disturbed (eutrophicated) and undisturbed eelgrass meadows of the Danish coast suggested that the physical setting of seagrass meadows (exposed vs sheltered; eutrophicated vs pristine) influences the ecosystem's structure, function and resilience (Thormar et al., 2016). The eelgrass meadows of Puck Bay persist throughout the year, and the export of the eelgrass-derived organic matter has been confirmed in the summer (Jankowska et al., 2018). Our results also indicated that even though the species of vegetated communities presented some seasonal dietary shifts, the trophic functioning of the whole community remained stable. Apparently, the meadow vegetation, even if it fluctuates seasonally in terms of its development, provides the conditions that stabilize the benthic food webs.

Climate change and anthropogenic pressures expose seagrasses to a number of challenges, thus significantly reducing their abundance (thermal pollution, $\mathrm{pH}$ decrease, increased storm frequency, rising sea level, Orth et al., 2006). As a consequence, over the past three decades, an accelerating loss of seagrass area has been noted worldwide (Waycott et al., 2009). In the Baltic Sea alone, large-scale losses of 60 to $100 \%$ in eelgrass area have been recorded in Denmark, Sweden and Poland between the 1900s and the mid-1980s (Boström et al., 2014). The greater number of storms and extreme weather conditions occurring in the Baltic Sea are considered to cause additional stress for coastal ecosystems (Jania and Zwoliński, 2011, Rotnicki et al., 1995). The documentation of the trophic structure and carbon flow in the benthic communities is crucial for understanding the whole ecosystem functioning in terms of food sources and capacity of the system to sustain different life stages of the top-predator populations including commercially important fish (Baden et al., 2012). Therefore, the present study increases the knowledge regarding the importance of 
seagrass meadows for the healthy functioning of the temperate shallow water ecosystems and emphasizes the importance of their conservation. Having more extensive and stable seagrass meadows could increase the region's resilience to future changes.

\section{Acknowledgments}

This study was completed thanks to the funds provided by grants from the Polish National Science Center, "Evaluation of the effects of seagrass meadows recovery on the functioning of the coastal ecosystem of the southern Baltic (FitFood)" grant 2014/15/N/NZ8/00321; the European Regional Development Fund, "ZOSTERA. Restitution of key elements of the inner Puck Bay ecosystem," POIS.05.01.00-00-205/0900; coordinated by Center of Coordination of Environmental Projects and Regional Directorate of Environmental Protection and Nature Conservation at the Pomeranian Voivodship. and statutory funds from the Institute of Oceanology Polish Academy of Sciences. We would like to thank Wojtek Moskal, Alicja Rozenbajger, Barbara Górska and Michał Procajło for their help with field work and sample analysis. This is MARE publication XXX.

\section{Appendix A. Supplementary data}

Supplementary data to this article can be found online at https:// doi.org/10.1016/j.jembe.2018.10.004.

\section{References}

Baden, S., Emanuelsson, A., Pihl, L., Svensson, C.J., Aberg, P., 2012. Shift in seagrass food web structure over decades is linked to overfishing. Mar. Ecol. Prog. Ser. 451, 61-73.

Baeta, A., Valiela, I., Rossi, F., Pinto, R., Richard, P., Niquil, N., Marques, J.C., 2009. Eutrophication and trophic structure in response to the presence of the eelgrass Zostera noltii. Mar. Biol. 156 (10), 2107-2120.

Bearhop, S., Adams, C., Waldron, S., Fuller, R., Macleod, H., 2004. Determining trophic niche width: a novel approach using stable isotope analysis. J. Anim. Ecol. 73 1007-1012.

Boström, Ch., Baden, S., Bockelmaan, A.Ch., Dromph, K., Fredriksen, S., Gustafsson, C., Krause-Jensen, D., Moller, T., Nielsen, S.L., Olesen, B., Olesen, J., Pihl, L., Rinde, E., 2014. Distribution, structure and function of Nordic eelgrass (Zostera marina) ecosystems: implications for coastal management and conservation. Aquat. Conserv. (3), 410-434.

Budge, S.M., Wooller, M.J., Springer, A.M., Iverson, S.J., McRoy, C.P., Divoky, G.J., 2008. Tracing carbon flow in an arctic marine food web using fatty acid stable isotope analysis. Oecologia 157 (1), 117-129.

Christianen, M.J.A., van Belzen, J., Herman, P.M.J., van Katwijk, M.M., Lamers, L.P.M., van Leent, P.J.M., Bouma, T.J., 2013. Low-canopy seagrass beds still provide important coastal protection services. PLoS One. https://doi.org/10.1371/journal.pone. 0062413.

De Troch, M., Steinarsdottir, M.B., Chepurnov, V., Olafsson, E., 2005. Grazing on diatoms by harpacticoid copepods: species-specific density-dependent uptake and microbial gardening. Aquat. Microb. Ecol. 39, 135-144.

Deniro, M.J., Epstein, S., 1981. Influence of diet on the distribution of nitrogen isotopes in animals. Geochim. Cosmochim. Acta 45, 341-351.

Drzycimski, I., 1985. Widłonogi denne Copepoda (Harpacticoida). In: Katalog Fauny Polski, 12. 4. PWN, Warszawa. (45 pp).

Fonseca, M., Koehl, M., 2006. Flow in seagrass canopies: the influence of patch width. Estuar. Coast. Shelf Sci. 67, 1-9.

Gartner, A., Tuya, F., Lavery, P.S., McMahon, K., 2013. Habitat preferences of macroinvertebrate fauna among seagrasses with varying structural forms. J. Exp. Mar. Biol. Ecol. 439, 143-151.

Harley, Ch.D.G., O'Riley, J.L., 2011. Non-linear density-dependent effects of an intertidal ecosystem engineer. Oecologia 166, 531-541.

Hedges, J.I., Stern, J.H., 1984. Carbon and nitrogen determinations of carbonate-containing solids. Limnol. Oceanogr. 29, 657-663.

Hemminga, M.A., Duarte, C.M., 2000. Seagrass Ecology. Cambridge University Press, Cambridge, pp. 298

Jackson, A.L., Inger, R., Parnell, A.C., Bearhop, S., 2011. Comparing isotopic nichewidths among andwithin communities: SIBER-Stable Isotope Bayesian Ellipses in R. J. Anim. Ecol. 80 (3), 595-602.

Jania, J.A., Zwoliński, Z., 2011. Extreme meteorological, hydrological and geomorphological events in Poland. Landform. Anal. 15, 51-64.

Jankowska, E., Włodarska-Kowalczuk, M., Kotwicki, L., Balazy, P., Kuliński, K., 2014. Seasonality in vegetation biometrics and its effects on sediment characteristics and meiofauna in Baltic seagrass meadows. Estuar. Coast. Shelf Sci. 139, 159-170.

Jankowska, E., Michel, L.N., Zaborska, A., Włodarska-Kowalczuk, M., 2016. Sediment carbon sink in low density temperate eelgrass meadows (Baltic Sea). J. Geophys. Res. Biogeosci. 121, 2918-2934. https://doi.org/10.1002/2016JG003424.
Jankowska, E., De Troch, M., Michel, L.N., Lepoint, G., Włodarska-Kowalczuk, M., 2018. Modification of benthic food web structure by recovering seagrass meadows, as revealed 2 by trophic markers and mixing models. Ecol. Indic. 90, 28-37.

Jaschinski, S., Brepohl, D.C., Sommer, U., 2008. Carbon sources and trophic structure in an eelgrass Zostera marina bed, based on stable isotope and fatty acid analyses. Mar. Ecol. Prog. Ser. 358, 103-114.

Jephson, T., Nyström, P., Moksnes, P., Baden, S.P., 2008. Trophic interactions in Zoster marina beds along the Swedish coast. Mar. Ecol. Prog. Ser. 369, 63-76.

Kotwicki, L., Szymelfenig, M., Fiers, F., Graca, B., 2014. Diversity and environmental control of benthic harpacticoids of an offshore post-dredging pit in coastal waters of Puck Bay. Baltic Sea. Mar. Biol. Res. 1 (6), 572-583.

Kruk-Dowigałło, L., 1991. Long term changes in the structure of underwater meadows of the Puck lagoon. Acta. Ichtiol. Piscat 77-84 Vol. XXI (Supplement).

Layman, C.A., Allgeier, J.E., 2012. Characterizing trophic ecology of generalist consumers: a case study of the invasive lionfish in the Bahamas. Mar. Ecol. Prog. Ser. 448, 131-141.

Layman, C.A., Arrington, D.A., Montana, C.G., Post, D.M., 2007. Can stable isotope ratios provide quantitative measures of trophic diversity within food webs? Ecology 88, $42-48$.

Lebreton, B., Richard, P., Galois, R., Radenac, G., Pfléger, C., Guillou, G., Mornet, F., Blanchard, G.F., 2011. Trophic importance of diatoms in an intertidal Zostera noltii seagrass bed: Evidence from stable isotope and fatty acid analyses. Estuar. Coast. Shelf. S. 92 (1), 140-153.

Lebreton, B., Richard, P., Galois, R., Radenac, G., Brahmia, A., Colli, G., Grouazel, M. André, C., Guillou, G., Blanchard, G.F., 2012. Food sources used by sediment meiofauna in an intertidal Zostera noltii seagrass bed: a seasonal stable isotope study. Mar. Biol. 159, 1537-1550.

Lehmann, M.F., Bernasconi, S.M., Barbieri, A., Mckenzie, J.A., 2002. Preservation of organic matter and alteration of its carbon and nitrogen isotope composition during simulated and in situ early sedimentary diagenesis. Geochim. Cosmochim. Acta 66 (20), 3573-3584.

Martínez del Rio, C., Wolf, N., Carleton, S.A., Gannes, L.Z., 2009. Isotopic ecology ten years after a call for more laboratory experiments. Biol. Rev. Camb. Philos. Soc. 84 91-111.

Mascart, T., Lepoint, G., De Troch, M., 2013. Meiofauna and harpacticoid copepods in different habitats of a Mediterranean seagrass meadows. J. Mar. Biol. Assoc. UK 93 (6), 1557-1566.

McCutchan, J.H., Lewis, W.M., Kendall, C., McGrath, C.C., 2003. Variation in trophic shift for stable isotope ratios of car- bon, nitrogen, and sulfur. Oikos 102, 378-390.

Michel, L.N., Dauby, P., Gobert, S., Graeve, M., Nyssen, F., Thelen, N., Lepiont, G., 2015. Dominant amphipods of Posidonia oceanica seagrass meadows display considerable trophic diversity. Mar. Ecol. 36 (4), 969-981.

Mittermayr, A., Hansen, T., Sommer, U., 2014. Simultaneous analysis of $\delta^{13} \mathrm{C}, \delta^{15} \mathrm{Nand}$ $\delta^{34} \mathrm{~S}$ ratios uncovers food web relationships and the trophic importance of epiphytes in an eelgrass Zostera marina community. Mar. Ecol. Prog. Ser. 497, 93-103.

Miyajima, T., Koike, I., Yamano, H., Iizumi, H., 1998. Accumulation and transport of seagrass-derived organic matter in reef flat sediment of Green Island, Great Barrier Reef. Mar. Ecol. Prog. Ser. 175, 251-259.

Moore, J.W., Semmens, B.X., 2008. Incorporating uncertainty and prior information into stable isotope mixing models. Ecol. Lett. 11, 470-480.

Nordström, M., Aarnio, K., Bonsdorff, E., 2009. Temporal variability of a benthic food web patterns and processes in a low-diversity system. Mar. Ecol. Prog. Ser. 378, $13-26$.

Orth, R., Carruthers, T., Dennison, W., Duarte, C., Fourqurean, J., Heck, K., Hughes, A., Kendrick, G., Kenworthy, W., Olyarnik, S., Short, F., Waycott, M., Williams, S., 2006. A global crisis for seagrass ecosystems. Bios 56, 987-996.

Ouisse, V., Riera, P., Migné, A., Leroux, C., Davoult, D., 2012. Food web analysis in intertidal Zostera marina and Zostera noltii communities in winter and summer. Mar. Biol. 159 (1), 165-175.

Peirano, A., Niccolai, I., Mauro, R., Bianchi, C.N., 2001. Seasonal grazing and food preference of herbivores in a Posidonia oceanica meadow. Sci. Mar. 65 (4), 367-374.

Phillips, D.L., Inger, R., Bearhop, S., Jackson, A.L., Moore, J., Parnell, A.C., Semmens, S.X., Ward, E.J., 2014. Best practices for use of stable isotope mixing models in food web studies. Can. J. Fish. Aquat. Sci. 835, 823-835.

Pihl, L., Rosenberg, R., 1984. Food selection and consumption of the shrimp Crangon crangon in some shallow marine areas in western Sweden. Mar. Ecol. Prog. Ser. 15, 159-168.

Pujol, D., Nepf, H., 2012. Breaker-generated turbulence in and above a seagrass meadow. Cont. Shelf Res. 49, 1-9.

Rossi, F., Herman, P.M.J., Middelburg, J.J., 2004. Inter- and intra-speciWc variation of $\mathrm{d} 13 \mathrm{C}$ and $\mathrm{d} 15 \mathrm{~N}$ in deposit- and suspension-feeding bivalves (Macoma balthica and Cerastoderma edule): evidence of ontogenetic changes in feeding mode of Macoma balthica. Limnol. Oceanogr. 49, 409-414.

Rotnicki, K., Borowka, R.K., Devine, N., 1995. Accelerated sea level rise as a threat to the Polish Coastal Zone - quantificationof risk. J. Coast. Res. SI 22, 111-135.

Rutkowski, S., 1982. Encyklopedia ryb morskich. Wydawnictwo Morskie, Gdańsk.

Sommer, F., Saage, A., Santer, B., Hansen, T., Sommer, U., 2005. Linking foraging strategies of marine calanoid copepods to patterns of nitrogen stable isotope signatures in a mesocosm study. Mar. Ecol. Prog. Ser. 286, 99-106.

Stock, B.C., Jacoson, A.L., Ward, E.J., Parnell, A.C., Phillips, D.L., Semmens, B.X., 2018 Analyzing mixing systems using a new generation of Bayesian tracer mixing models. PeerJ Preprints 6, e26884v1. https://doi.org/10.7287/peerj.preprints.26884v1.

Syväranta, J., Lensu, A., Marjomäki, T.J., Oksanen, S., Jones, R.I., 2013. An empirical evaluation of the utility of convex hull and standard ellipse areas for assessing population niche widths from stable isotope data. PLoSONE 8 (2), e56094. https://doi org/10.1371/journal.pone.0056094. 
Thormar, J., Hasler-Sheetal, H., Baden, S., Boström, Ch., Clausen, K.K., Krause-Jensen, D., Olesen, B., Rasmussen, J.R., Svensson, C.J., Holmer, M., 2016. Eelgrass (Zostera marina) food web structure in different environmental settings. PLoS One 11 (1) e0146479. https://doi.org/10.1371/journal. pone.0146479.

Vafeiadou, A.M., Materatski, P., Adão, H., De Troch, M., Moens, T., 2013. Food sources of macrobenthos in an estuarine seagrass habitat (Zostera noltii) as revealed by dual stable isotope signatures. Mar. Biol. 160 (9), 2517-2523.

Vizzini, S., Sarà, G., Michener, R.H., Mazzola, A., 2002. The role and contribution of the seagrass Posidonia oceanica (L.) Delile organic matter for secondary consumers as revealed by carbon and nitrogen stable isotope analysis. Acta Oecol. 23, 277-285.

Waycott, M., Duarte, C., Carruthers, T., Orth, R.J., 2009. Accelerating loss of seagrasses across the globe threatens coastal ecosystems. P. Nat. Acad. Sci. 106, 12377-12381. Włodarska-Kowalczuk, M., Jankowska, E., Kotwicki, L., Balazy, P., 2014. Evidence of season-dependency in vegetation effects on macrofauna in temperate seagrass meadows (Baltic Sea). PLoS One 9 (7), e100788. https://doi.org/10.1371/journal.pone. 0100788.

Wu, Y., Wang, N., Zhang, J., Ruijing, W., Fangqun, D., Xianshi, J., 2016. Chin. J. Oceanol. Limnol. 34, 1085.

Yeakel, J.D., Bhat, U., Emma, A., Smith, E., Newsom, S.D., 2016. Exploring the isotopic niche: isotopic variance, physiological incorporation, and the temporal dynamics of foraging. Front. Ecol. Evol. https://doi.org/10.3389/fevo.2016.00001. 